\title{
Redescription of Campoletis sonorensis (Cameron, 1886) (Hymenoptera, Ichneumonidae, Campopleginae), parasitoid of Spodoptera frugiperda (J. E. Smith, 1797) (Lepidoptera, Noctuidae) in Brazil
}

\author{
L. F. Camargo ${ }^{a *}$, R. A. Brito and A. M. Penteado-Dias $^{c}$ \\ aPrograma de Pós-Graduação em Ecologia e Recursos Naturais, Universidade Federal de São Carlos - UFSCar, \\ Rodovia Washington Luiz, Km 235, CEP 13565-905, São Carlos, SP, Brazil \\ bDepartamento de Genética e Evolução, Universidade Federal de São Carlos - UFSCar, \\ Rodovia Washington Luiz, Km 235, CEP 13565-905, São Carlos, SP, Brazil \\ 'Departamento de Ecologia e Biologia Evolutiva, Universidade Federal de São Carlos - UFSCar, \\ Rodovia Washington Luiz, Km 235, CEP 13565-905, São Carlos, SP, Brazil \\ *e-mail: luizafigueiredocamargo@hotmail.com
}

Received: March 19, 2014 - Accepted: June 25, 2014 - Distributed: November 30, 2015

(With 30 figures)

\begin{abstract}
The fall armyworm Spodoptera frugiperda (Lepidoptera; Noctuidae) is a voracious pest of numerous crops of economic importance throughout the New World. In Brazil, its larvae are attacked by several species of parasitoid wasps, making them potential candidate as biological control agents against this pest. A survey of the parasitoid fauna on $S$. frugiperda in maize crops throughout Brazil reveals two species of Campoletis, which are morphologicaly very similar species. In this paper we combine these data with pictures from the type material of C. sonorensis and C. flavicincta, as well as their descriptions to provide a redescription to Campoletis sonorensis (Cameron, 1886) using for this both morphological characters and DNA Barcoding (Hebert et al., 2003) information, in an attempt to help with the correct identification of the taxa to improve biological control studies.
\end{abstract}

Keywords: agriculture, molecular biology, economic importance, morphology, taxonomy.

\section{Redescrição de Campoletis sonorensis (Cameron, 1886) (Hymenoptera, Ichneumonidae, Campopleginae), parasitoide de Spodoptera frugiperda (J. E. Smith, 1797) (Lepidoptera, Noctuidae) no Brasil}

\section{Resumo}

Spodoptera frugiperda é uma praga voraz de diversas culturas de importância econômica no Novo Mundo. No Brasil, suas larvas podem ser atacadas por diversas espécies de vespas parasitóides que são candidatos a agentes de controle biológico contra essa praga. Pesquisando os parasitóides da fauna de Spodoptera frugiperda em cultivos de milho no Brasil foram encontradas duas espécies do gênero Campoletis, muito similares morfologicamente. Este trabalho apresenta uma redescrição para Campoletis sonorensis usando caracteres morfológicos e DNA Barcoding (Hebert et al., 2003) com o objetivo de evitar erros de identificação desse grupo, aprimorando estudos de controle biológico.

Palavras-chave: agricultura, biologia molecular, importância econômica, morfologia, taxonomia.

\section{Introduction}

The genus Campoletis Foerster (Hymenoptera, Ichneumonidae: Campopleginae: Campoplegini) includes various species that are parasitoids of Noctuidae larvae (Lepidoptera) therefore being a relevant taxa for biological control (Porter, 1998; Virla et al., 1999). This genus contains a very large number of species some of which are morphologically very conservative, which makes its species delimitation considerably difficult (Townes, 1970). Species of this genus have a wide geographic distribution, occurring from North to South America (McCutcheon, 1991; Lucchini and Almeida, 1980). Campoletis currently comprises six recognized species in the neotropical region, most of which occur in open habitats (Townes, 1970).

Campoletis sonorenis (Cameron, 1886) and C. flavicincta (Ashmed, 1890) are morphologically similar and frequently confused. Carlson (1972) proposed C. perdistincta as a 
synonym of $C$. flavicincta, mentioning that $C$. sonorensis was misidentified as Campoletis perdistincta.

After Viereck, Campoletis sonorensis has one synonym as Campoletis websteri. It was reported to occur in Bermuda, Brazil, Chile, Honduras, Mexico and United States with the following hosts species: Anthocharis midea (Hubner, [1809]) (Lepidoptera, Pieridae), Autographa californica (Speyer, 1875) (Lepidoptera: Noctuidae), Colias eurytheme Boisduval, 1832 (Lepidoptera, Pieridae), Copitarsia incommode (Walker, 1865) (Lepidoptera, Noctuidae), Eoreuma loftini (Dyar, 1917) (Lepidoptera, Crambidae), Helicoverpa zea (Boddie, 1850) (Lepidoptera, Noctuidae), Heliothis phloxiphaga Grote \& Robinson, 1867 (Lepidoptera, Noctuidae), Heliothis virescens (Fabricius, 1777) (Lepidoptera, Noctuidae), Hypena scabra (Fabricius, 1798) (Lepidoptera, Erebidae), Peridroma saucia (Hübner, [1808]) (Lepidoptera, Noctuidae), Pseudoplusia includes (Walker, [1858]1857) (Lepidoptera, Noctuidae), Rachiplusia $n u$ (Guenée, 1852) (Lepidoptera, Noctuidae), Schinia bina (Guenée, 1852) (Lepidoptera, Noctuidae), Schinia chrysellus (Grote, 1874) (Lepidoptera, Noctuidae), Spodoptera exigua (Hübner, [1808]) (Lepidoptera, Noctuidae), Spodoptera frugiperda (Smith, 1797) (Lepidoptera, Noctuidae), Spodoptera ornithogalli (Guenée, 1852) (Lepidoptera, Noctuidae), Trichoplusia ni (Hübner, [1803]) (Lepidoptera, Noctuidae) (Yu et al., 2012).

Campoletis flavicincta has already had the synonyms: Limneria flavicincta Ashmead (1890), Amorphota nocturna Viereck (1905), Limnerium perdistinctus (Viereck, 1905), Limnerium prodeniar Viereck (1911), Sagaritis modestus (Viereck, 1925, 1926), Sagaritis trochanteralis (Viereck, 1925, 1926) and Sagaritis twinni (Viereck, 1925, 1926). This species occurs in Brasil, Canada, Honduras, Mexico, Nicaragua, Peru, United States and Uruguay and has been recorded on the following hosts: Achyra rantalis (Guenée, 1854) (Lepidoptera, Crambidae), Agrotis ipsilon (Hufnagel, 1766) (Lepidoptera, Noctuidae), Agrotis subterranean (Fabricius, 1794) (Lepidoptera, Noctuidae), Colias eurytheme Boisduval, 1832 (Lepidoptera, Pieridae), Dargida procinctus (Grote, 1873) (Lepidoptera, Noctuidae), Euxoa messoria (Harris, 1841) (Lepidoptera, Noctuidae), Helicoverpa armigera (Hübner, [1809]) (Lepidoptera, Noctuidae), Helicoverpa zea (Boddie, 1850) (Lepidoptera, Noctuidae), Heliothis virescens (Fabricius, 1777) (Lepidoptera, Noctuidae), Hypena scabra (Fabricius, 1798) (Lepidoptera, Erebidae), Lacinipolia stricta (Walker, 1865) (Lepidoptera, Noctuidae), Manduca quinquemaculata (Haworth, 1803) (Lepidoptera, Sphingidae), Ostrinia nubilalis (Hübner, 1796) (Lepidoptera, Cambridae), Phthorimaea operculella (Zeller, 1873) (Lepidoptera, Gelechiidae), Pieris rapae (Linnaeus, 1758) (Lepidoptera, Pieridae), Pseudaletia sequax Franclemont, 1951 (Lepidoptera, Noctuidae), Pseudaletia unipuncta (Haworth, 1809) (Lepidoptera, Noctuidae), Sesamia inferens (Walker, 1856) (Lepidoptera, Noctuidae), Spodoptera eridania (Stoll, 1782) (Lepidoptera, Noctuidae), Spodoptera exigua (Hübner, [1808]) (Lepidoptera, Noctuidae), Spodoptera frugiperda (Smith, 1797) (Lepidoptera, Noctuidae), Spodoptera ornithogalli (Guenée, 1852) (Lepidoptera, Noctuidae), Syngrapha epigaea (Grote, 1874) (Lepidoptera, Noctuidae), Trichoplusia ni (Hübner, [1803]) (Lepidoptera, Noctuidae), Udea rubigalis (Guenée, 1854) (Lepidoptera,Crambidae) (Yu et al., 2012).

Campoletis flavicincta is cited as an important natural enemy of Spodoptera frugiperda, known as the main corn pest in the American continent (Cruz, 1995) that can reduces corn production in more than 50\% (Cruz and Turpin, 1982, 1983; Figueiredo et al., 2006). It is an endoparasitoid of first and second instars of Noctuidae larvae which reduce their leaf consumption to $6,9 \%$ (Cruz et al., 1997; Matrangolo et al., 2007).

A complete, accurate knowledge about the taxonomy and biology of natural enemies is essential to ensure the efficiency of biological control. The use of taxonomical and molecular techniques could solve misidentification, allowing studies on the biology of this important specie for biological control.

DNA Barcoding is a standard gene sequence for the identification of species being a useful tool for the taxonomy of complicated species. That sequence is a fragment belonging to the cytochrome $c$ oxidase subunit 1 (COI) gene which usually allows discriminating closely related animal species (Smith et al., 2009; Hebert et al., 2003; Floyd et al., 2002). Hebert et al. (2003) was able to discriminate closely related species of lepidopterans, a group with high species diversity and moderate rates of molecular evolution. The COI has two important advantages, first the universal primers for this gene are very robust recovering of its 5' end from representatives of most animal phyla (Folmer et al., 1994; Zhang and Hewitt, 1997); second it has a great range of phylogenetic signal (Knowlton and Weigt, 1998).

In this work we studied specimens of Campoletis emerged from larvae of Spodoptera frugiperda, from three different regions of the Brazil. These wasps were morphologically and molecularly characterized using the barcoding locus in order to assess their species boundaries. This represents the first complete morphological study for a species of Campoletis.

\section{Material and Methods}

Parasitoid wasps were reared in laboratory from Spodoptera frugiperda specimens collected on corn field in Santa Maria (RS), Ribeirão Preto (SP) and Sete Lagoas (MG). All specimens were preserved in 100\% ethanol and deposited at the "Coleção Taxonômica do Departamento de Ecologia e Biologia Evolutiva, Universidade Federal de São Carlos, São Carlos”, SP, Brazil (DCBU) (as shown in Table 1).

Specimens were identified to genus level using Townes (1970) key, as well as the original description of C. flavicincta (Ashmead, 1890) and C. sonorensis (Cameron, 1886). Moreover, our examined specimens were compared with pictures of type material deposited at National Museum of Natural History, Washington DC, USA and the Natural History Museum, London, UK. The morphological 
Table 1. Data collection.

\begin{tabular}{|c|c|c|c|c|c|}
\hline Local & $\begin{array}{l}\text { Geographic } \\
\text { coordinates }\end{array}$ & Data collection & Females & Males & $\begin{array}{l}\text { Number of } \\
\text { individuals }\end{array}$ \\
\hline Santa Maria, RS & $\begin{array}{l}29^{\circ} 42^{\prime} 23 ” \mathrm{~S} \\
53^{\circ} 43^{\prime} 15^{\prime \prime} \mathrm{W}\end{array}$ & Nov-Dec/2010 e Jan-Feb/2011 & 194 & 227 & 421 \\
\hline Sete Lagoas, MG & $\begin{array}{l}19^{\circ} 28^{\prime} 00 ” \mathrm{~S} \\
44^{\circ} 15^{\prime} 00^{\prime \prime} \mathrm{W}\end{array}$ & Dec/2010-May/2011 & 9 & 12 & 21 \\
\hline $\begin{array}{l}\text { Ribeirão Preto, } \\
\text { SP }\end{array}$ & $\begin{array}{l}21^{\circ} 10^{\prime} 42^{\prime \prime} \mathrm{S} \\
47^{\circ} 48^{\prime} 24 ’ \mathrm{~W}\end{array}$ & Feb-Mar/2005 & 7 & 2 & 9 \\
\hline Total & & & & & 451 \\
\hline
\end{tabular}

terminology employed follows Townes (1969) and the sculpture terminology follows Eady (1968).

Digital SEM photographs were taken with a FEI QuantaTM 250 SEM in a low vacuum mode. Colour digital photographs were taken with a Leica ${ }^{\circledR}$ Z16 APO-A stereoscopic microscope and a Leica ${ }^{\circledR}$ DFC295/DFC290 HD camera, and edited with the Leica application Suite ${ }^{\circledR}$ program.

\subsection{Laboratory procedures}

Genomic DNA was extracted from the whole wasp or from the wasp's abdomen using the DNeasy tissue kit (QIAGEN) following the manufacturer's instructions and the DNA extracts was resuspended in $100 \mathrm{ul}$ of elution buffer. One or two specimens from each of the morphologically distinctive group were sequenced. The COI fragment belonging to the barcoding locus was amplified using the universal LCO1490 and HCO 2198 primers (Folmer et al., 1994). The polymerase chain reaction (PCR) conditions were an initial desnaturation of $94{ }^{\circ} \mathrm{C}(1: 30 \mathrm{~m})$ followed by a 3 cycles of $94{ }^{\circ} \mathrm{C}$ desnaturation $(30 \mathrm{~s}), 51{ }^{\circ} \mathrm{C}$ anneling $(30 \mathrm{~s}), 72^{\circ}$ elongation $(1 \mathrm{~m})$, followed by a 35 cycles of $94{ }^{\circ} \mathrm{C}$ denaturation (30s), $48^{\circ} \mathrm{C}$ anneling (30 s), $72^{\circ}$ elongation $(1 \mathrm{~m})$, ending with a final elongation at $72{ }^{\circ} \mathrm{C}$ for 5 minutes. The PCR product was PEG8000 (Lis and Schleif, 1975) purified and sequenced on an ABI 3010 at Macrogen Inc. (Seoul, Korea) using the same primers.

Sequences were aligned using the program Bioedit 7.2. The genus Dusona was chosen as outgroup because of its proximity with Campoletis, both Campoplegini. A maximum likelihood (ML) tree was reconstructed with MEGA 5.03 (Tamura et al., 2011) using the Tamura 3-Parameter (T92, Tamura, 1992) evolutionary model, which was found as the most appropriate model of nucleotide substitution for our dataset by hierarchic likelihood ratio test in MEGA 5.03 $(-\operatorname{lnL}=384.866, \mathrm{BIC}=899.159, \mathrm{AIC}=804.037)$. Bootstrap analysis used 1000 pseudoreplicates (Felsenstein, 1985). A neighbour-joining analysis and intra- and interspecific genetic distances were based on the Kimura-2-parameter model (K2-P, Kimura, 1980) with the program MEGA 5.03 (Tamura et al., 2011) for comparison with other barcoding studies. Additionally, we compared all our generated sequences with the Campoletis group dataset deposited in the BOLD system (www.boldsystems.org). The sequences were selected using the BOLD identification engine. Only sequences published in Gene Bank were considered.

\section{Results and Discussion}

A total of 451Campoletis specimens were examined all of which agreed with the description of $C$. flavicincta. However, these specimens showed various morphological differences and thus we segregated them into seven morphospecies named as UFSCARCM1, UFSCARCM2, UFSCARCM3, UFSCARCM4, UFSCARCM5, UFSCARCM6, UFSCARCM7. Morphological differences include those of the pedicel coloration, legs coloration, sculpture of the pronotum, mesopleuron, propodeum and the wing venation.

C. flavicincta is very similar to $C$. sonorensis and there is considerable confusion with their description and identification. Carlson (1972) compared these two species and separated them according to coloration of their hind tibia. The differences include "discrete areas of dark and light coloration" in $C$. sonorensis, whereas these are "rather indiscrete" in Cflavicincta. The head structure was another character used by this author to distinguish both species. According to him, females of $C$. flavicincta have the median field of the face very weakly raised, so that face is nearly flat. Females of $C$. sonorensis, on the other hand, have the median $1 / 3$ to $1 / 4$ of the face distinctly convex. The clypeus of $C$. flavicincta is more truncate than the one observed in C. sonorensis. In C. sonorensis the petiolar area of the propodeum is usually distinctly concave, whereas in C. flavicincta the concavity of the petiolar area usually is scarcely discernible. The ovipositor of C. flavicicnta is somewhat more strongly compressed laterally and more strongly upcurved than that of $C$. sonorensis.

One or two Barcoding sequences were generated for each morphospecies. The aligned sequences had a length of $717 \mathrm{bp}$ and only contained 9 variable sites $(1.25 \%)$ none of which was parsimonious informative. Most of these variable sites occurred in the third codon position and the sequences were heavily AT-biased, specifically in the latter position (as shown in Table 2).

The maximum likelihood (ML) tree including all our generated sequences is showed in Figure 1 while the maximum likelihood bootstrap method (K2-P) (Kimura, 1980) with the same data is showed in Figure 2. These trees and the corrected genetic distances (as shown in Figure 3) do not support the allospecificity of any of the examined morphospecies, indicating this only represents intraspecific variation.

The morphological differences observed on our specimens showed a continuous variation among them. Pictures 
Table 2. Variable and informative sites and average nucleotide composition in the analysed COI gene sequence.

\begin{tabular}{ccccccc}
\hline Nucleotide Position & \% Variable sites & \% Informative sites & $\mathbf{\% A}$ & $\mathbf{\% C}$ & $\mathbf{\% G}$ & $\mathbf{\% T}$ \\
\hline $1^{\circ}$ & 0.33 & 0 & 41.2 & 10.8 & 19.2 & 29 \\
$2^{\circ}$ & 0.11 & 0 & 19.2 & 22.4 & 13 & 45 \\
$3^{\circ}$ & 0.55 & 0 & 49.2 & 2.6 & 0.9 & 47 \\
All & 1.25 & 0 & 36.5 & 11.9 & 11 & 40.5 \\
\hline
\end{tabular}

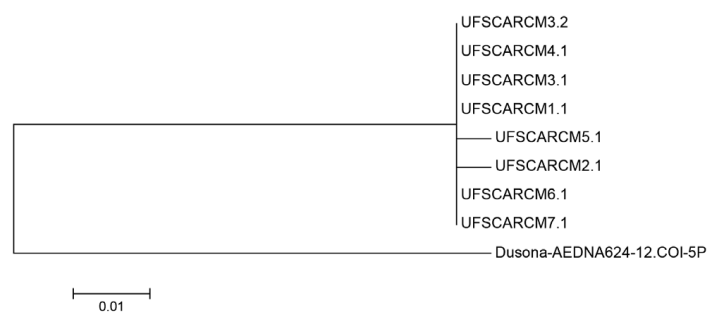

Figure 1. Maximum likelihood tree of Campoletis morphospecies based on partial COI sequences, using Tamura 3- parameter.
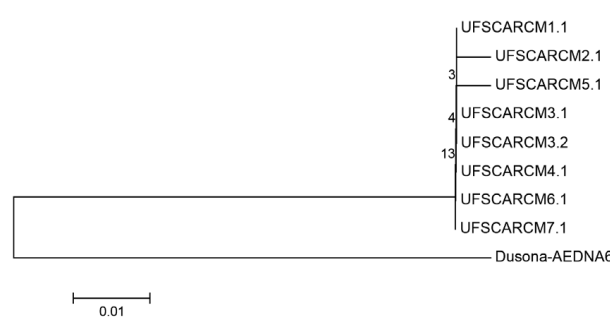

Figure 2. Neighbor join tree of Campoletis morphospecies, based on partial COI sequences, using Tamura 2- parameter.

\begin{tabular}{|c|c|c|c|c|c|c|c|c|} 
& 1 & 2 & 3 & 4 & 5 & 6 & 7 & 8 \\
\hline 1. UFSCARCM1.1 & & & & & & & & \\
\hline 2. UFSCARCM2.1 & 0.004 & & & & & & & \\
\hline 3. UFSCARCM3.1 & 0.000 & 0.004 & & & & & & \\
\hline 4. UFSCARCM3.2 & 0.000 & 0.004 & 0.000 & & & & & \\
\hline 5. UFSCARCM4.1 & 0.000 & 0.004 & 0.000 & 0.000 & & & & \\
\hline 6. UFSCARCM5.1 & 0.004 & 0.009 & 0.004 & 0.004 & 0.004 & & & \\
\hline 7. UFSCARCM6.1 & 0.000 & 0.004 & 0.000 & 0.000 & 0.000 & 0.004 & & \\
\hline 8. UFSCARCM7.1 & 0.000 & 0.004 & 0.000 & 0.000 & 0.000 & 0.004 & 0.000 & \\
\hline
\end{tabular}

Figure 3. Genetic distances using Kimura-2-parameter.

of the type material of $C$. sonorensis and $C$. flavicincta showed some morphological differences among them, which are the same, found on our specimens, like the color variations on the median tibia, coxae and on the posterior femur (see Figures 4-5). Beyond that, those pictures do not corroborate what Carlson (1972) said about the color of the hind tibia, character considered the most relevant by him.

Redescription of Campoletis sonorensis (Cameron, 1886) (Figures 6-28)

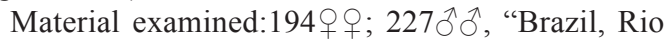
Grande do Sul, Santa Maria, Campus from Universidade Federal de Santa Maria (UFSM), 2942'23'S e 5343'15'W, 1/xi/2010-04/xii/2010 e 22/i/2011-22/ii/2011, Sturza,V. col."; 7 우우, $2 \hat{\jmath}$ 소, “Brazil, São Paulo, Ribeirão Preto, $21^{\circ} 10^{\prime} 42$ ”S e 4748'24”W, ii/2005-iii/2005, A. S. Pinto col.”; 9 우, $12 \widehat{\jmath} \partial^{\lambda}$, "Brazil, Minas Gerais, Sete Lagoas, Embrapa Milho e Sorgo,19²8'00'S 44¹5'00”W, xii/2010-vi/2011, R. Braga col."

Female: Length 4.0-6.0mm. Black (Figure 6), pedicel sometimes brown, mandible yellowish with apex brown, palpi pale yellowish (Figure 7), anterior and middle coxae varying from all orange yellow (Figure 8) to all dark brown (Figure 9), most commonly orange yellow with base brown (Figure 10), posterior coxa black (Figure 10) sometimes ventrally brown (Figure 11) when the posterior femur all orange. Posterior femur orange (Figure 12), variable with brown ring at the base (Figure 14), weak or nonexistent dorsally; the apex with a dorsal brown spot strong, weak or nonexistent. In some specimens with all coxae black, the femur is dorsally completely brown (Figure 13); anterior and middle trochanters and trochantelus pale, posterior trochanter black, posterior trochantelus pale, anterior femur and tibia orange, middle femur orange (Figure 10), sometimes with a brown spot in the inside base (Figure 9), mainly when the anterior and middle coxae are black. The middle tibia is light brown, dorsal and laterally pale yellow from the base to the $3 / 4$ length (Figure 14) or light brown, pale at the base and at the middle (Figure 15). Posterior tibia brown varying with pale areas dorsally at base and median (Figure 16), laterally as a median strip inside and outside (Figure 17). Tarsi light brown to brown. Metasoma black, with yellow at the thyridium and apex of the tergites, principally from the II to the last (Figure 18). Ventrally, the metasoma is pale, sometimes with a brown spot on the third sternite or from the second to de fifth. Antennae with 29-31 segments, covered with white hairs, face flat covered with white hairs, clypeous truncate with a median tooth (Figure 7). Mesosoma punctulate covered with white hairs (Figure 21); pronotum varying from granulose (Figure 22) to crenulate (Figure 23); mesopleuron, punctulate, smooth (Figure 24) or lightly crenulate (Figure 25) in the middle part, above the sternaulus. Propodeum with areola open (Figure 26) or closed hexagonal (Figure 27) or roundish (Figure 28). The peciolar area is rough strigose (Figure 26).

Wings hyaline, with bristles, stigma and veins brown. Areolete closed, often petiolate, with second recurrent vein based (Figure 20), some specimens with areolete open in one or both wings (Figure 19).

Male: similar to female.

The reconstructed maximum likelihood (ML) tree including all available Campoletis sequences obtained from the BOLD system (see Figure 29) showed that the sequence of all our specimens have the same COI haplotype or are very similar to several sequences from BOLD that are assigned both as Campoletis sonorensis and as C. flavicincta. Moreover, two groups of sequences downloaded 

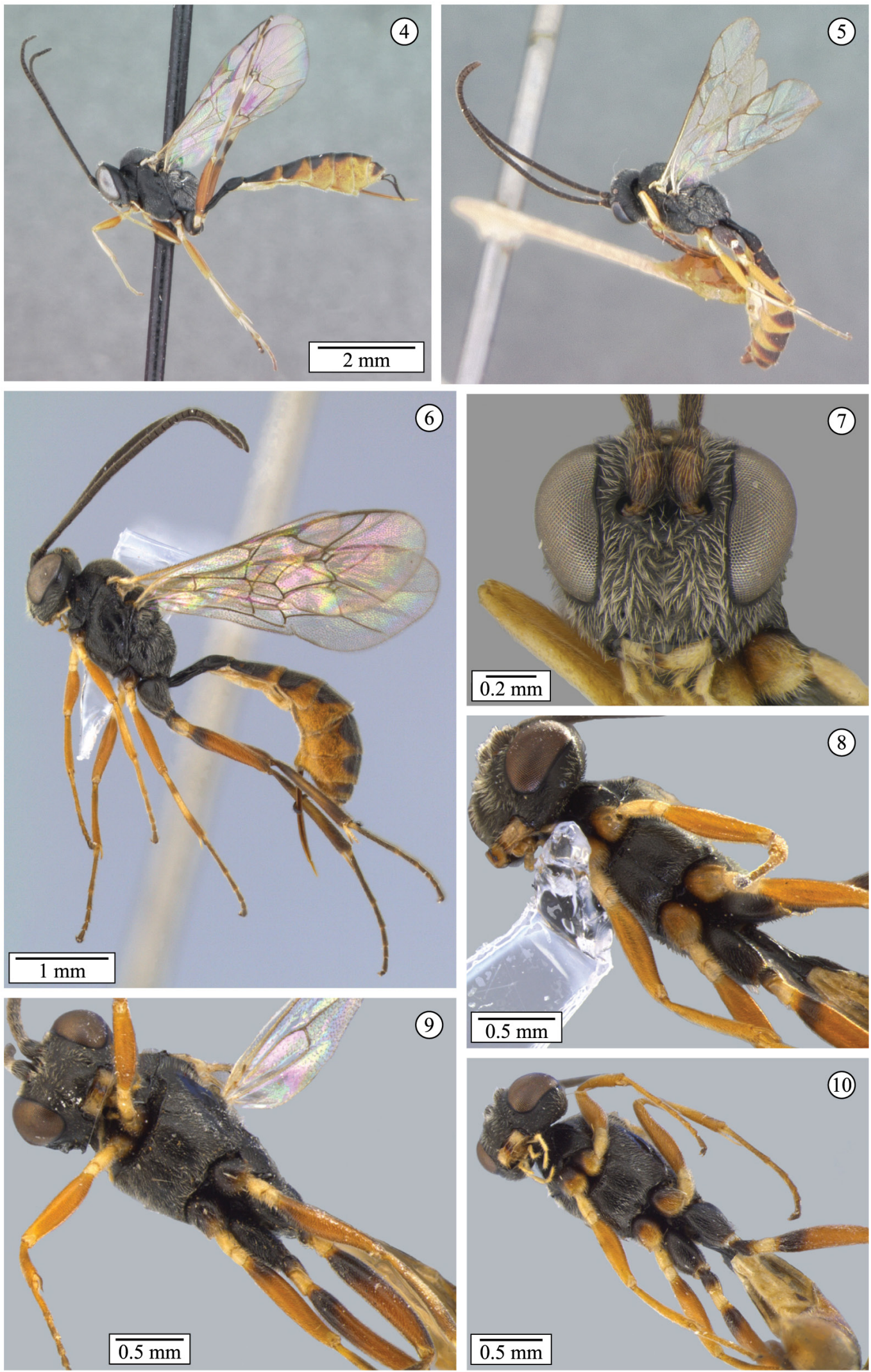

Figures 4-10. 4.Campoletis sonorensis female homotype; 5. C.flavicincta male lectotype; 6. C. sonorensis habitus lateral view; 7. C. sonorensis head, frontal view; 8-10. C. sonorensis mesosoma ventral view, with attention to legs. 

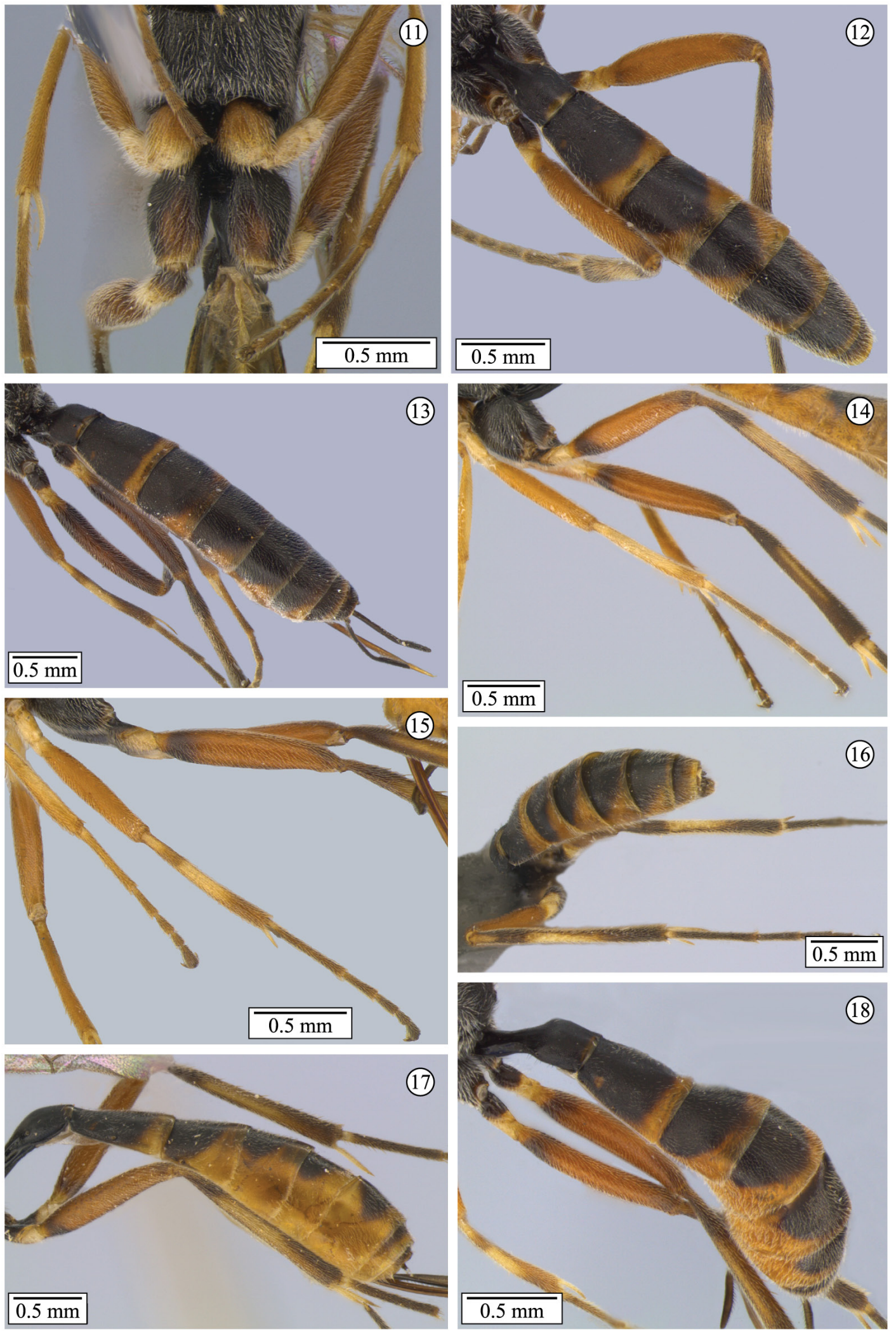

Figures 11-18. C. sonorensis, 11. posterior coxae, ventral view; 12-13. posterior femur, dorsal view; 14. posterior femur and middle tibia, lateral view; 15. middle tibia, lateral view; 16. posterior tibia, dorsal view; 17. posterior tibia, lateral view; 18. metasoma dorsal view. 

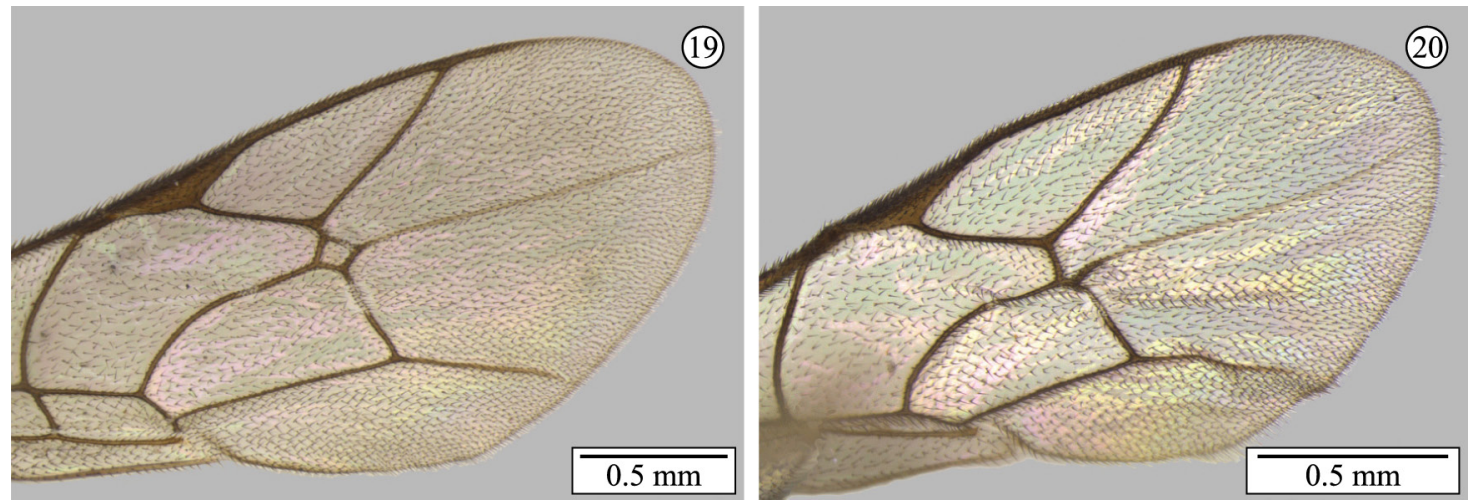

Figures 19-20. C. sonorensis, anterior wings, with attention to areolet.
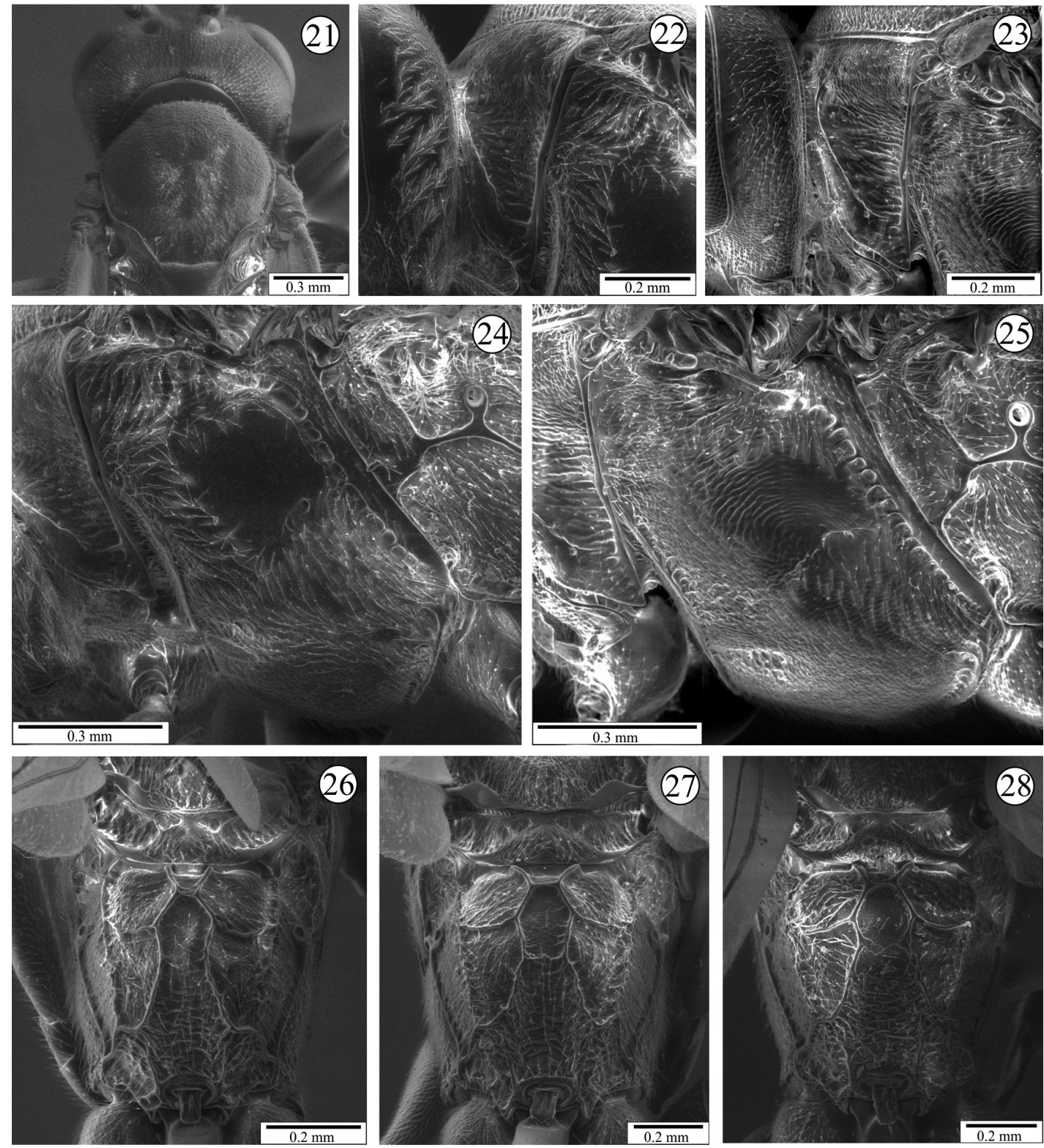

Figures 21-28. C. sonorensis. 21. mesoscutum dorsal view; 22-23. pronotum lateral view; 24- 25. mesopleuron lateral view; 26-28. propodeum dorsal view. 


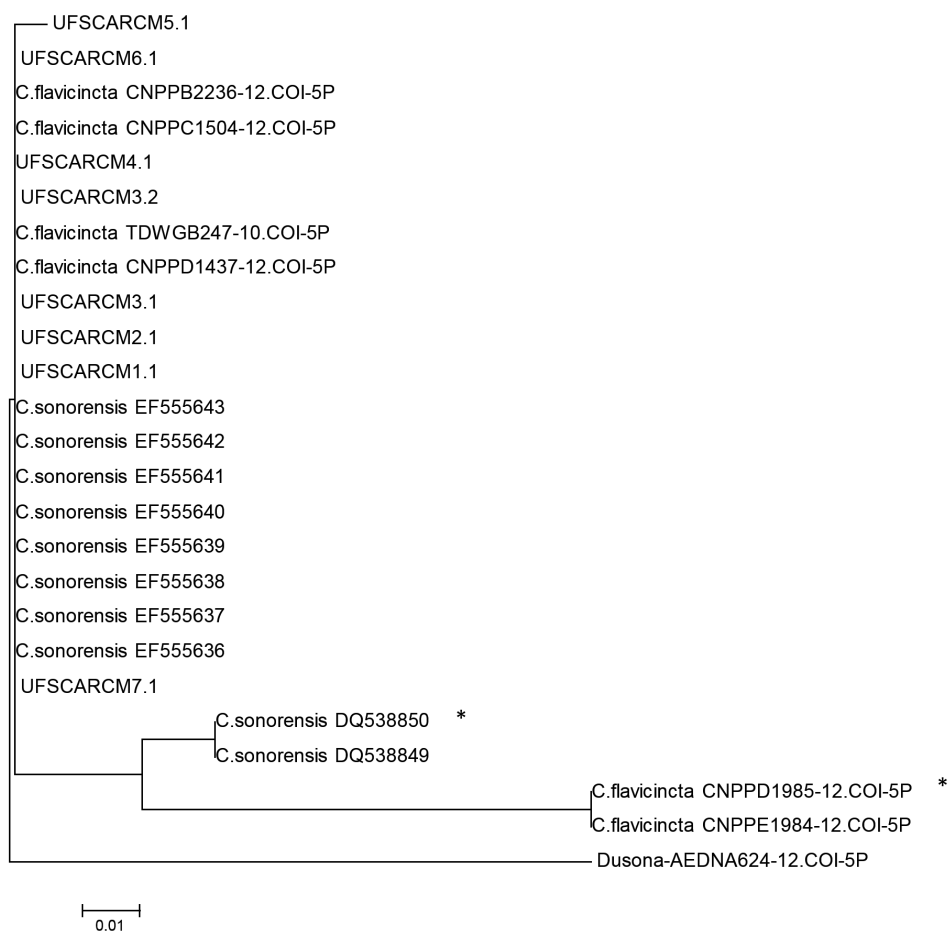

Figure 29. The maximum likelihood (ML) tree produced with the former sequences to the full Campoletis group dataset in BOLD and our species groups, based on partial COI sequences, using Tamura 3- parameter.

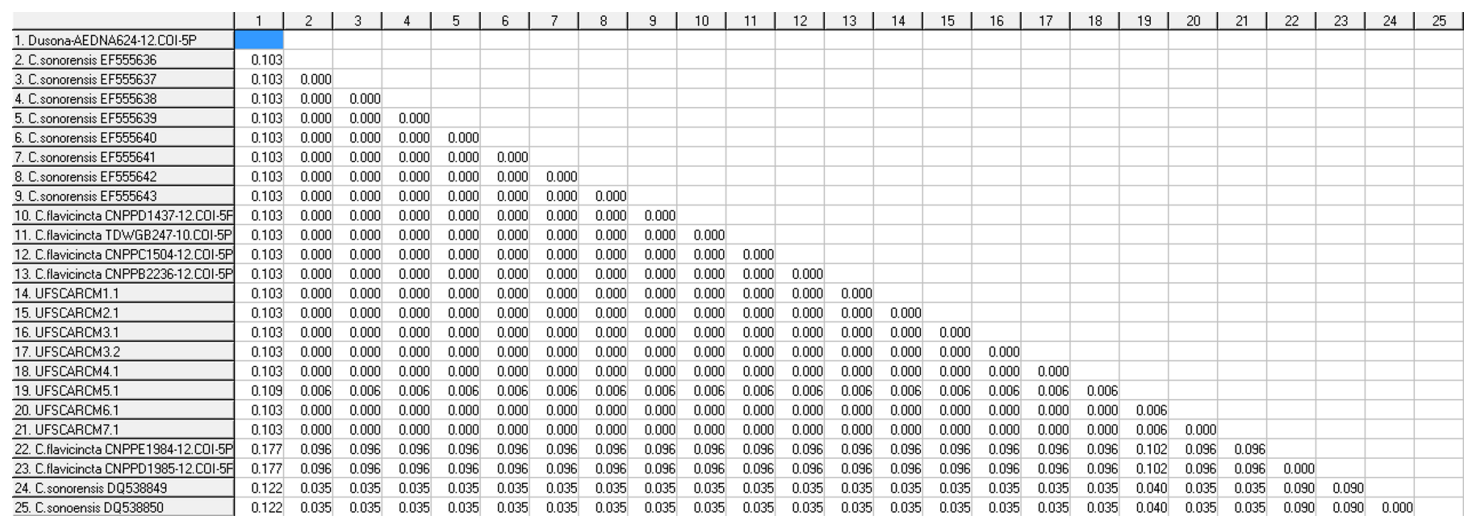

Figure 30. Genetic Distances to sequences obtained from BOLD and our sequences.

from BOLD, one assigned to Campoletis sonorensis, and the other assigned to C. flavicincta are considerably distinct from the other sequences. The genetic distances shows 0.096 from the group assigned as C. flavicincta to ours specimens, and 0.035 from the group assigned as C. sonorensis to our specimens, while the outgroup distances were 0.103 (as shown in Figure 30). These results suggest C. flavicincta and C. sonorensis should be synonymized, and that the two groups of distinct sequences $(*)$ represent different species with misidentifications.

As the two species are too similar in their biology, distribution, morphology and DNA analysis we could propose to synonymize both. However, a further study, including more specimens from the entire geographic distribution of these two species is necessary in order to confirm this. Nevertheless, we propose use the name Campoletis sonorensis (Cameron, 1886) to species that attacks Spodoptera frugiperda on South and Southeast of Brazil and we provide here a redescription, to avoid further misidentifications.

\section{Acknowledgements}

To CNPq (Conselho Nacional de Desenvolvimento Científico e Tecnológico), FAPESP (Fundação de Amparo à Pesquisa do Estado de São Paulo), INCT - HYMPAR/SUDESTE (Instituto Nacional de Ciência e Tecnologia dos Hymenoptera Parasitoides da Região Sudeste Brasileira) for financial 
support; to the curators Gavin Broad (Natural History Museum, London, UK) and Robert Kula (National Museum of Natural History, Washington, DC, USA) for sending the pictures of type material; to Vinicius Soares Sturza (Instituto Federal Forroupilha), Rafael Braga da Silva (Embrapa Milho e Sorgo) and Valmir Costa (Instituto Biológico) for sending the material; to Alejandro Zaldívar Ríveron, Sara Ceccarelli, André Luís Andrade Lima and Fabio Laurindo for help with genetic studies, to Luciana Fernandes for help with the illustrations.

\section{References}

CARLSON, R.W., 1972. Suppresion of the name Campoletis perdistincta (Hymenoptera: Ichneumonidae) and the identity of species to which the name has been applied. Entomological News, vol. 83, pp. 75-82.

CRUZ, I. and TURPIN, F.T., 1982. Efeito da Spodoptera frugiperda em diferentes estádios de crescimento da cultura de milho. Pesquisa Agropecuária Brasileira, vol. 17, pp. 355-359.

CRUZ, I. and TURPIN, F.T., 1983. Yield impact of larval infestations of the Fall Armyworm (Lepidoptera: Noctuidae) to midwhorl growth stage of corn. Journal of Economic Entomology, vol. 76, no. 5, pp. 1052-1054. http://dx.doi.org/10.1093/jee/76.5.1052.

CRUZ, I., 1995. A lagarta-do-cartucho na cultura do milho. Sete Lagoas: Embrapa-CNPMS. 45 p. Embrapa-CNPMS: Circular Técnica, vol. 21

CRUZ, I., FIGUEIREDO, M.L.C., GONÇALVES, E.P., LIMA, D.A.N. and DINIZ, E., 1997. Efeito da idade de lagartas de Spodoptera frugiperda (Smith) (Lepidoptera: Noctuidae) no desempenho do parasitóide Campoletis flavicincta (Ashmead) (Hymenoptera: Ichneumonidae) e consumo foliar por lagartas parasitadas e não parasitadas). Anais da Sociedade Entomológica do Brasil, vol. 26, no. 2, pp. 229-234. http://dx.doi.org/10.1590/ S0301-80591997000200003.

EADY, R.D., 1968. Some illustrations of microsculpture in the Hymenoptera. Proceedings of the Royal Entomological Society of London. Series A, General Entomology, vol. 43, no. 4-6, pp. 66-72. http://dx.doi.org/10.1111/j.1365-3032.1968.tb01029.x.

FELSENSTEIN, J., 1985. Confidence limits on phylogenies: an approach using the bootstrap. International Journal of Organic Evolution, vol. 39, no. 4, pp. 783-791. http://dx.doi. org/10.2307/2408678.

FIGUEIREDO, M.L.C., MARTINS-DIAS, A.M.P. and CRUZ, I., 2006. Relação entre a lagarta do cartucho e seus agentes de controle biológico natural na produção de milho. Pesquisa Agropecuária Brasileira, vol. 41, no. 12, pp. 1693-1698. http:// dx.doi.org/10.1590/S0100-204X2006001200002.

FLOYD, R., ABEBE, E., PAPERT, A. and BLAXTER, M., 2002. Molecular barcodes for soil nematode identification. Molecular Ecology, vol. 11, no. 4, pp. 839-850. http://dx.doi.org/10.1046/ j.1365-294X.2002.01485.x. PMid:11972769.

FOLMER, O., BLACK, M., HOEH, W., LUTZ, R. and VRIJENHOEK, R., 1994. DNA primers for amplification of mitochondrial cytochrome c oxidase subunit I from diverse metazoan invertebrates. Molecular Marine Biology and Biotechnology, vol. 3, no. 5, pp. 294-299. PMid:7881515.
HEBERT, P.D.N., CYWINSKA, A., BALL, S.L. and DEWAARD, J.R., 2003. Biological identifications through DNA barcodes. Proceedings. Biological Sciences, vol. 270, no. 1512, pp. 313322. http://dx.doi.org/10.1098/rspb.2002.2218. PMid:12614582.

KIMURA, M., 1980. A simple method for estimating evolutionary rates of base substitutions through comparative studies of nucleotide sequences. Journal of Molecular Evolution, vol. 16, no. 2, pp. 111-120. http://dx.doi.org/10.1007/BF01731581. PMid:7463489.

KNOWLTON, N. and WEIGT, L.A., 1998. New dates and new rates for divergence across the Isthmus of Panama. Proceedings. Biological Sciences, vol. 265, no. 1412, pp. 2257-2263. http:// dx.doi.org/10.1098/rspb.1998.0568.

LIS, J.T. and SCHLEIF, R., 1975. Size fractionation of doublestranded DNA by precipitation with polyethylene glycol. Nucleic Acids Research, vol. 2, no. 3, pp. 383-390. http://dx.doi.org/10.1093/ nar/2.3.383. PMid:236548.

LUCCHINI, F. and ALMEIDA, A.A., 1980. Parasitas da Spodoptera frugiperda (Smith \&Abbot, 1797) (Lep., Noctuidae), lagartas do cartucho do milho encontradas em Ponta Grossa, PR. Anais da Sociedade Entomológica do Brasil, vol. 9, no. 1, pp. 115-121.

MATRANGOLO, W.J.R., MARTINS-DIAS, A.M.P. and CRUZ, I., 2007. Aspectos biológicos de Campoletis flavicincta (Ashmead) (Hymenoptera:Ichneumonidae) e interações com o vírus da poliedrose nuclear de Spodoptera frugiperda. Revista Brasileira de Milho e Sorgo, vol. 6, pp. 1-16.

MCCUTCHEON, G.S., 1991. Late-season parasitoids of the fall armyworm in South Carolina. Journal of Agriculture Entomololy, Clemson, vol. 8, no. 3, pp. 219-221.

PORTER, C.C., 1998. Guía de los Géneros de Ichneumonidae em la region Neantértica del sur de sudamérica. Tucumán: Fundación Miguel Lillo. 234 p. Opera lilloana, vol. 42.

SMITH, M.A., FERNANDEZ-TRIANA, J.L., ROUGHLEY, R. and HEBERT, P.D.N., 2009. DNA barcode accumulation curves for understudied taxa and areas. Molecular Ecology Resources, vol. 9, no. 1, suppl. 1, pp. 208-216. http://dx.doi.org/10.1111/j.17550998.2009.02646.x. PMid:21564980.

TAMURA, K., 1992. Estimation of the number of nucleotide substitutions when there are strong transition-transversion and $\mathrm{G}+\mathrm{C}$ content biases. Molecular Biology and Evolution, vol. 9, no. 4, pp. 678-687. PMid:1630306.

TAMURA, K., PETERSON, D., PETERSON, N., STECHER, G., NEI, M. and KUMAR, S., 2011. MEGA5: Molecular evolutionary genetics analysis using maximum likelihood, evolutionary distance, and maximum parsimony methods. Molecular Biology and Evolution, vol. 28, no. 10, pp. 2731-2739. http://dx.doi. org $/ 10.1093 / \mathrm{molbev} / \mathrm{msr} 121$. PMid:21546353.

TOWNES, H., 1969. The genera of Ichneumonidae, part 1. Gainesville: American Entomological Institute, pp. 1-300. Memoirs of the American Entomological Institute, vol. 11.

TOWNES, H., 1970. The genera of Ichneumonidae, part 2. Gainesville: American Entomological Institute, pp. 1-537. Memoirs of the American Entomological Institute, vol. 12.

VIRLA, E.G., COLOMO, M.V., BERTA, C. and VALVERDE, L., 1999. El complejo de los parasitóides del "gusano cogollero" Del maíz, Spodoptera frugiperda, em La República Argentina (Lepidoptera: Noctuidae). Neotrópica, vol. 45, pp. 3-12. 
YU, D.S.K., ACHTERBERG, C.V. and HORSTMANN, K., 2012.

Taxonomy, biology, morphology and distribution. In: TAXAPAD.

Word Ichneumonoidea 2011. Vancouver: FlashDrive.
ZHANG, D.X. and HEWITT, G.M., 1997. Assessment of the universality and utility of a set of conserved mitochondrial primers in insects. Insect Molecular Biology, vol. 6, no. 2, pp. 143-150. http://dx.doi.org/10.1111/j.1365-2583.1997.tb00082.x. PMid:9099578. 